\title{
Manifestations and environmental implications of microbially-induced calcium carbonate precipitation (MICP) by the cyanobacterium Dolichospermum flosaquae
}

Refat Abdel-Basset ${ }^{1 *}$, Elhagag Ahmed Hassan ${ }^{1 \wedge}$ and Hans-Peter Grossart ${ }^{2,3+}$

${ }^{1 *}$ Botany and Microbiology Department, Faculty of Science, Assiut University, 71516 Assiut (Egypt)

${ }^{2}$ Dept. Experimental Limnology, Leibniz Institute for Freshwater Ecology and Inland Fisheries, D-16775 Stechlin, Germany

${ }^{3}$ Dept. of Biochemistry and Biology, Potsdam University, 14469 Potsdam, Germany

^ elhagaghassan@aun.edu.eg

* hgrossart@igb-berlin.de

*Correspondance to: rbasset@aun.edu.eg

Abstract. The aim of this work is to explore the ability and magnitude of the temperate cyanobacterium Dolichospermum flosaquae in microbially-induced calcium carbonate precipitation (MICP). Environmentally, MICP controls the availability of calcium, carbon and phosphorus in freshwater lakes and simultaneously controls carbon exchange with the atmosphere. Cultures of flosaquae were grown in BG11 medium containing $0,1,1.5,2$ and $4 \mathrm{mg} \mathrm{Ca}{ }^{2+} \mathrm{L}^{-1}$, as cardinal concentrations previously reported in freshwater lakes, in addition to a control culture (BG11 containing $13 \mathrm{mg}$ $\mathrm{Ca}^{2+} \mathrm{L}^{-1}$ ). Growth (cell number, chlorophyll a, and protein content) of $D$. flosaquae was generally reduced by elevating calcium concentrations of the different salts used (chloride, acetate, or citrate). D. flosaquae exhibited its ability to perform MICP as carbonate alkalinity was sharply increased up to its highest level (six times that of the control) at a citrate concentration of $4 \mathrm{mg} \mathrm{Ca}^{2+} \mathrm{L}^{-1}$. Calcium carbonate was formed at a pre-precipitation stage as the minimum $\mathrm{pH}$ necessary for precipitation (8.7) has been scarcely approached under such conditions. In this work, MICP took place mostly empowered by photosynthesis and respiration. Residual calcium exhibited its lowest value at $4 \mathrm{mg} \mathrm{Ca}^{2+}$ citrate $\mathrm{L}^{-1}$, coinciding with the highest alkalinity level. Precipitated calcium was increased with chlorophyll a content, but not with increasing cell numbers. 
Key Words: Dolichospermum flosaquae - MICP - Photosynthesis - Respiration Urease - Alkalinity - Calcium

\section{Introduction}

Microbially-induced calcium carbonate precipitation (MICP) depicts an exogenous or endogenous microbial activity that takes place during heterotrophic growth of numerous fungi and bacteria or during photoautotrophic growth of cyanobacteria in their natural environments including water, soils, tufas, biofilms or geological formations. Furthermore, bacterial, and cyanobacterial mucilaginous sheath (capsular polysaccharides or exopolysaccharides) as well as fungal chitin act as nucleation sites for $\mathrm{CaCO}_{3}$ crystallization by binding $\mathrm{Ca}^{2+}$ onto their carboxylic groups. MICP requires sufficient $\mathrm{Ca}^{2+}$, an alkaline $\mathrm{pH}$ and suitable microorganisms. Availability of nucleation sites is very important for stable and continuous calcium carbonate bio-mineralization (Phillips et al 2013). In particular, cyanobacteria are active prokaryotes performing MICP (Payandi-Rolland 2019; Xu et al 2019). Furthermore, morphology of the calcite crystal is strain-specific (Hammes et al 2003) and depends on the type of the calcium salt present (Achal and Pan 2014). Several metabolic processes such as photosynthesis, respiration, sulfate, nitrate or sulfide reduction and ureolytic activity have been recorded as driving mechanisms for MICP (e.g. Seifan et al 2019; CastroAlonso et al 2019). Although these metabolic pathways are diverse, either of them empowers MICP by conserving $\mathrm{CO}_{2}$, as a component of calcium carbonate, and ammonia to shift the $\mathrm{pH}$ into alkalinity as a prerequisite environmental feature for the process.

Subsequent to coprecipitation of calcium and carbon(ate), chemically and/or microbially to form calcium carbonate, the bioavailability of both calcium and carbon becomes limited. Calcium and phosphate also coprecipitate and thus get lowered at these conditions. Limited bioavailability of these elements, in turn, arises as ratelimiting to growth and nutrition of aquatic microbiota, e.g. via photosynthetic activity in the case of cyanobacteria. This MICP process is widely explored and regarded as a promising phenomenon for use in various industrial applications. MICP may be responsible (at least in part) for the widespread threat of calcium decline in freshwater lakes around the globe, as calcium co-precipitates simultaneously with carbonate 
(Jeziorski and Smol 2017). After studying 440,599 water samples from 43,184 inland water sites in 57 American and European countries, Weyhenmeyer et al (2019) concluded that the global median calcium concentration was $4.0 \mathrm{mg} \mathrm{L}^{-1}$ with $20.7 \%$ of the water samples showing $\mathrm{Ca}^{2+}$ concentrations $\leq 1.5 \mathrm{mg} \mathrm{L}^{-1}$, a threshold considered critical for the survival of many $\mathrm{Ca}^{2+}$ dependent organisms, e.g. Daphnia (Jeziorski et al 2014). Anthropogenic activities, namely acid depositions, are detrimental to calcium decline. Since some time ago, governments determined to prevent acid deposition into lakes; acid deposition solubilizes calcium (Korosi et al 2012), i.e. no acid deposition means less calcium dissolution. Another explanation is that the acid deposition preceded such measures may have led to depletion of calcium in soil catchments leaving no more of the element to dissolve.

The hypothesis of this work is to explore whether Dolichospermum flosaquae, a major temperate cyanobacterium, is able to perform MICP in freshwater lakes. Dependence of MICP magnitude on $\mathrm{Ca}^{2+}$ concentration and salt type of chloride, acetate or citrate as well as the empowering metabolic process are also tested in this study. Photosynthesis, respiration, total alkalinity and urease activity of $D$. flosaquae are measurables assessed to elucidate their role in mediating MICP and to detect the effect of the applied treatments. The results obtained are discussed on the lights of their anticipated environmental impact and implications.

\section{Materials and Methods}

\subsection{Experimental Set up}

Cultures of the local strain of the cyanobacterium Dolichospermum flosaquae were incubated at different $\mathrm{Ca}^{2+}$ concentrations $\left(0,1,1.5,2\right.$ and $\left.4 \mathrm{mg} \mathrm{Ca}^{2+} \mathrm{L}^{-1}\right)$ of different salts (chloride "Cl", acetate "Ac", or citrate "Cit") supplemented into calcium free BG11 medium specific for cyanobacteria (Rippka and Herdman 1993). D. flosaquae was also grown in full BG11 medium (containing $13 \mathrm{mg} \mathrm{Ca}^{2+} \mathrm{L}^{-1}$, which is considered the control culture "Con+") in addition to a reference calcium-deprived culture (BG11 devoid of any supplemental calcium "Con-"). Culture media were inoculated with $10 \mathrm{ml}$ of 5 days old cells of $D$. flosaquae in conical flasks capped with aluminum foil. Cultures were shaken for 4 weeks at $22 \pm 1{ }^{\circ} \mathrm{C}$ and white light intensity of $25 \mu$ mole $\mathrm{m}^{-2} \mathrm{sec}^{-1}$ (14h light:10h dark cycle). $D$. flosaquae exhibited a relatively long lag phase, most probably 
because of relatively low temperature for cyanobacteria, which grow optimally at higher temperatures. The temperature was set up to be close as much as possible to the average of Lake Stechlinsee.

\subsection{Analytical Methods}

At the end of the experiment, i.e. after growth for 4 weeks, the following parameters of the variously treated $D$. flosaquae cultures were analyzed and assessed as follows:

- Cell number and chlorophyll a were simultaneously assessed using a YSImultiparameter probe.

- Protein contents were estimated according to the method of Bradford (1976). Cells were extracted in boiled water, centrifuged and soluble proteins were assessed in the supernatant. The binding of protein molecules with the Coomassie Brilliant Blue dye under acidic conditions results in a color change from brown to blue, measured at a wavelength of $595 \mathrm{~nm}$ using a BioTek Synergy 2, multidetector microplate reader (Vermont, USA).

- Total alkalinity was assessed by titration of $50 \mathrm{~mL}$ algal culture media with $0.1 \mathrm{M} \mathrm{HCl}$ following Choi et al (2017) and Xu et al (2019), and then calculated using the following equation:

$$
\mathrm{CaCO}_{3}+2 \mathrm{HCl} \rightarrow \mathrm{CaCl}_{2}+\mathrm{H}_{2} \mathrm{O}+\mathrm{CO}_{2}
$$

Based on the reaction stoichiometry between $\mathrm{CaCO}_{3}$ and $\mathrm{HCl}$, the molar ratio of $\mathrm{CaCO}_{3}$ to $\mathrm{HCl}$ is $1: 2$; by dividing the number of moles of $\mathrm{HCl}$ by 2 , the product is the number of moles of $\mathrm{CaCO}_{3}$. The number of moles of $\mathrm{CaCO}_{3}$ would be multiplied by its molecular weight to get the yielded respective $\mathrm{CaCO}_{3}$ mass.

- Photosynthetic activity: The light-induced $\mathrm{O}_{2}$ evolution by $D$. flosaquae in different cultures was followed by means of an oxygen sensor (PreSens MicroXTX3O sensor, Software $\mathrm{T} \times 3 \mathrm{v} 6 \mathrm{O}_{2}$, Presens, Germany) at the same growth conditions (white light intensity of about $25 \mu$ mole $\mathrm{m}^{-2} \mathrm{sec}^{-1}$ at room temperature, i.e. $22 \pm 1^{\circ} \mathrm{C}$ ). Respiration $\left(\mathrm{O}_{2}\right.$ uptake) was also monitored using the same oxygen sensor, but in the dark.

- Assessment of residual free $\left[\mathrm{Ca}^{2+}\right]$ in the growth media: At the end of the experiment, calcium was assayed by calcium kits (ab102505, Calcium Detection Assay Kit- 
colorimetric, abcam) and determined at a wavelength of $575 \mathrm{~nm}$ using a BioTek Synergy 2, multidetector microplate reader (Vermont, USA). Consumed calcium was then calculated by subtracting residual from total calcium.

- Urease enzyme (UE) activity was assayed spectrophotometrically following the procedure of Mobley et al (1988) and quantified using a calibration curve of ammonia. The assay mixture of UE contained intact cells of $D$. flosaquae, urea (200 $\mathrm{mM})$, phenol red $\left(7 \mu \mathrm{g} \mathrm{mL}^{-1}\right)$ and phosphate buffer $(\mathrm{pH} \mathrm{6.8)}$. After $10 \mathrm{~min}$, the developed color, as a result of liberated ammonia from urea hydrolysis, was determined at a wavelength of $500 \mathrm{~nm}$ using the same microplate reader (as described above).

- Ammonia accumulated in the different culture media at the end of the experimental period was assessed as mentioned above in urease-liberated ammonia.

- The $\mathrm{pH}$ values of the differently treated cultures were determined via a $\mathrm{pH}$ meter (WTW3301, Germany)

All experiments and assessments were conducted in triplicates and the mean values \pm SE (standard error) are presented in figures.

\section{Results}

Under culture conditions, growth indices (cell number, chlorophyll - and soluble protein contents) of Dolichospermum flosaquae were variably affected in response to calcium concentration as well as to its counter anion (chloride, acetate, or citrate). Growth of $D$. flosaquae decreased as calcium concentrations of all salts were lowered following a relative growth enhancement (higher than the control) at a threshold value of 1.5$2.0 \mathrm{mg} \mathrm{Ca}^{2+} \mathrm{L}^{-1}$ of the calcium salts citrate and acetate, respectively, while continually lowered by calcium chloride. Calcium-deprived cultures (Co-) exhibited markedly lower growth rates than $\mathrm{Ca}^{2+}$ supplemented ones $(\mathrm{Co}+)$ in terms of cell number, chlorophyll a and protein contents (Fig. 1). 
The $\mathrm{pH}$ of 7.0 was set for all $D$. flosaquae cultures at the beginning of the experiment; thereafter, it was elevated to levels ranging between $\mathrm{pH} 8.0-8.7$, depending on calcium treatment (Fig. 2). A certain calcium concentration of each salt induced a higher $\mathrm{pH}$ than control or calcium-deprived cultures. The highest $\mathrm{pH}$ elevation (up to 8.7) occurred at calcium chloride and calcium citrate concentrations of $1 \mathrm{mg} \mathrm{Ca}^{2+} \mathrm{L}^{-1}$ but decreased at higher concentrations. However, $\mathrm{Ca}^{2+}$ acetate resulted in the highest $\mathrm{pH}$ elevation (up to 8.7) at the highest added concentration (4 $\mathrm{mg} \mathrm{Ca}^{2+} \mathrm{L}^{-1}$ ). Accordingly, the $\mathrm{pH}$ elevation depended on the calcium concentrations and type of $\mathrm{Ca}^{2+}$ salt (chloride, acetate or citrate) added.

Fig. (3) presents the net photosynthetic oxygen evolution $\left(\mathrm{P}_{\mathrm{N}}\right)$ and dark respiratory oxygen uptake $\left(\mathrm{R}_{\mathrm{D}}\right)$ of $D$. flosaquae in dependence on the imposed calcium treatments. $P_{N}$ was severely inhibited in calcium deprived cultures of $D$. flosaquae relative to control cultures while $R_{D}$ was enhanced. Different calcium salts exerted different impacts, but in most calcium treatments, net photosynthetic oxygen evolution was higher than in the control cultures. In calcium chloride and acetate treated cultures of $D$. flosaquae, $P_{N}$ and $R_{D}$ enhanced with increased concentrations of calcium while in citrate treated $D$. flosaquae cultures, both $\mathrm{P}_{\mathrm{N}}$ and $\mathrm{R}_{\mathrm{D}}$ decreased. Photosynthesis: respiration $\left(\mathrm{P}_{\mathrm{N}}: \mathrm{R}_{\mathrm{D}}\right)$ ratios, which represent the net productivity of cells or cultures, were severely inhibited by calcium deprivation while calcium chloride, acetate and citrate induced inhibition or stimulation of $\mathrm{P}_{\mathrm{N}}: \mathrm{R}_{\mathrm{D}}$, depending on the calcium concentration.

Total alkalinity ( $T$ alkalinity), ammonia as well as corrected carbonate alkalinity values (C alkalinity), calculated by subtracting ammonia concentration from total alkalinity of the differently treated $D$. flosaquae cultures, are shown in Fig. (4). Total alkalinity exhibited its absolutely lowest value in the control culture of $D$. flosaquae, despite it contained the highest $\mathrm{Ca}^{2+}$ concentration (13 $\mathrm{mg} \mathrm{Ca}^{2+} \mathrm{L}^{-1}$ ) while calcium deprivation remarkably enhanced alkalinity up to three times that of the control cultures (5 to 15 mmol carbonate $\mu \mathrm{g} \mathrm{Chl}^{-1}$ ). Furthermore, alkalinity level in any of the calcium treated cultures was markedly higher than that of the control or calcium-deprived cultures, with a maximum alkalinity level at calcium citrate concentration of $4 \mathrm{mg} \mathrm{Ca}^{2+} \mathrm{L}^{-1}$. All calcium acetate concentrations induced more or less similar alkalinity levels whereas calcium 
chloride induced its highest stimulation at $2 \mathrm{mg} \mathrm{Ca}^{2+} \mathrm{L}^{-1}$. As ammonia may interfere with carbonate alkalinity, ammonia has been assessed and detected in trace amounts not affecting total alkalinity (Fig. 4).

Residual calcium was assessed while total and consumed fractions were calculated (per $\mathrm{mL}$ culture and per unit chlorophyll) and presented in Figs. (5a\&b); consumed calcium means its incorporation into or precipitation as calcium carbonate. It is important to mention that in calcium-deprived cultures, i.e. without any external supplementation, calcium concentration was still $2.26 \mathrm{mg} \mathrm{Ca}^{2+} \mathrm{L}^{-1}$, nevertheless. This amount might have been released from cellular apoplastic regions as well as from intracellular stores. Therefore, a virtual concentration of total calcium is given to account for the externally supplemented concentration of calcium $(0,1,1.5,2$ or $4 \mathrm{mg}$ $\mathrm{Ca}^{2+} \mathrm{L}^{-1}$ ) and the amount of calcium found at calcium-deprivation (i.e. $2.26 \mathrm{mg} \mathrm{Ca}^{2+} \mathrm{L}^{-}$ $\left.{ }^{1}\right)$, which was assumed to be equally released by each culture. Control cultures displayed the highest levels of all calcium fractions as they started at the highest total virtual concentration of $15.26 \mathrm{mg} \mathrm{Ca}^{2+} \mathrm{L}^{-1}$ (i.e. $13 \mathrm{mg} \mathrm{Ca}^{2+} \mathrm{L}^{-1}$ in $\mathrm{BG} 11$ plus $2.26 \mathrm{mg}$ $\mathrm{Ca}^{2+} \mathrm{L}^{-1}$ released). On the contrary, calcium-deprived cultures exhibited the lowest levels of all calcium fractions since no calcium had been added and thus the released calcium was the only calcium resource.

Residual calcium (in the culture media) and consumed calcium (per unit chlorophyll and per unit volume) increased with elevated calcium additions (Fig $5 \mathrm{a}$ ). The lowest amounts of residual calcium were recorded in citrate treated cultures (almost equal to the consumed fraction and about $50 \%$ of total calcium). The concentration of $4 \mathrm{mg}$ citrate $\mathrm{L}^{-1}$ enhanced the calcium consumption nearly up to that of the control despite the big difference in the externally supplemented calcium concentration (4 vs. $13 \mathrm{mg}$ $\mathrm{Ca}^{2+} \mathrm{L}^{-1}$, respectively). In chloride and acetate, residual calcium was considerably higher indicating less incorporation into calcium carbonate. Consumed calcium per unit chlorophyll $\left(\mathrm{Ca} . \mathrm{Chl}^{-1}\right)$ was increasing with increasing supplemented calcium concentration; the highest enhancement was recorded at citrate (Fig 5b).

Urease enzyme (UE) activity is presented in Fig (6); specific activity "SA" represents the rate of enzyme activity as $\mu$ mole ammonia released $\mu \mathrm{g}^{-1}$ protein $\mathrm{min}^{-1}$ while total activity "TA" represents the rate of enzyme activity as $\mu$ mole ammonia released $\mathrm{mL}^{-1}$ 
224 algal suspension $\min { }^{1}$. Total activity is the product of specific activity per $\mu g$ protein multiplied by the amount of protein per unit volume $(\mathrm{mL})$ of algal cultures. Calcium deprivation inhibited UE activity; the magnitude of inhibition on a volume basis "TA" was more pronounced than the enzyme specific activity "SA" because enzyme (protein) contents were also lower. Calcium chloride induced the highest rates of UE, total and specific activity, at $1.5 \mathrm{mg} \mathrm{Ca}^{2+} \mathrm{L}^{-1}$; otherwise, it was inhibitory at lower or higher concentrations. Calcium acetate induced the highest rates of "TA" and "SA" at moderate concentrations of 1.5 and $2 \mathrm{mg} \mathrm{Ca}^{2+} \mathrm{L}^{-1}$, both lowest and highest concentrations of 1 and $4 \mathrm{mg} \mathrm{Ca}^{2+} \mathrm{L}^{-1}$ severely inhibited the enzyme activity. Calcium citrate induced a continuous increase in urease activity (SA) up to its "absolutely" highest rate at $4 \mathrm{mg} \mathrm{Ca}^{2+} \mathrm{L}^{-1}$ among other concentrations and salts; such highest rate of urease activity was in accordance with the highest level of calcium consumption, i.e. calcium may be inductive to urease activity in $D$. flosaquae. The order of UE enhancement was as follows citrate $>$ acetate $>$ chloride.

\section{Discussion}

Our results indicate, for the first time, that Dolichospermum flosaquae is able to perform microbially-induced calcium carbonate precipitation (MICP). Therefore, the intensive blooms of this organism have the potential to contribute to controlling the overall biogeochemical dynamics in freshwater bodies, depending on the availability of calcium, carbon, and phosphorus, in addition to controlling carbon emissions into the atmosphere. Calcium precipitates carbon in the form of calcium carbonate either chemically or microbially and precipitates phosphorus in the form of calcium phosphate. Furthermore, any calcium carbonate precipitate is a good binder of phosphate (Yanamadala 2005). In this work, the capability of the cyanobacterium $D$. flosaquae in freshwater MICP was studied at different concentrations of three calcium salts (chloride, acetate, and citrate). It is proved that different salt types and calcium concentrations exerted different impacts on $D$. flosaquae growth and metabolism. The studied concentrations $\left(0,1,1.5,2\right.$ and $\left.4 \mathrm{mg} \mathrm{Ca}^{2+} \mathrm{L}^{-1}\right)$ were chosen from previous records in the literature (Weyhenmeyer et al 2019). These authors reported that the global median calcium concentration was $4.0 \mathrm{mg} \mathrm{L}^{-1}$ with $20.7 \%$ of the water samples showing $\mathrm{Ca}^{2+}$ concentrations of $\leq 1.5 \mathrm{mg} \mathrm{L}^{-1}$, a threshold considered critical for the survival of many organisms. Growth of $D$. flosaquae in terms of cell number, protein - 
and chlorophyll a content, was inhibited by calcium deprivation as well as by higher concentrations of calcium. However, concentrations of only $1.5 \mathrm{mg} \mathrm{Ca}^{2+} \mathrm{L}^{-1}$ in the form of acetate and citrate were stimulatory for $D$. flosaquae growth.

D. flosaquae seems able to perform MICP, as inferred from alkalinity levels in the growth media, elevated $\mathrm{pH}$ values, and residual vs. consumed calcium levels. However, MICP occurred but at a pre-precipitation stage since no precipitation has been seen by naked eyes, due to the inability of the organism to surpass the minimum $\mathrm{pH}$ threshold under our experimental conditions of inactive urease due to absence of urea (discussed later). Therefore, ammonia concentrations were found to be marginal in the culture media; its interference with carbonate alkalinity can be thus ruled out indicating that the assessed alkalinity levels are substantially carbonate alkalinity. Carbonate alkalinity exhibited the lowest levels at control cultures but increased upon calcium deprivation. However, it was induced up to its maximum level (six times that of the control) by the highest calcium concentration of the citrate salt (4 $\left.\mathrm{mg} \mathrm{Ca}^{2+} \mathrm{L}^{-1}\right)$. This notion suggests that the capacity of $D$. flosaquae for carbonate formation depends on both salt type as well as $\mathrm{Ca}^{2+}$ concentration. In this respect, calcium chloride has been recorded to be the best salt for the production of calcite by Bacillus sp. among several other calcium sources used (Achal and Pan 2014). In this work, however, calcium citrate seems fitting to the studied organism more than chloride or acetate.

Alkaline $\mathrm{pH}$ is a prerequisite for calcium carbonate formation and stability. Most calcite precipitation occurs under alkaline conditions of pH values from 8.7 to 9.5 (Ferris et al 2003; Dupraz et al 2009). When pH levels decrease, carbonates tend to dissolve rather than precipitate (Loewenthal and Marais 1982). D. flosaquae exhibited a continuous ability of elevating the $\mathrm{pH}$ of the culture medium to high $\mathrm{pH}$ values, which in turn, may have caused a slow and long lag phase of growth, but favorable conditions for MICP. However, as long as the $\mathrm{pH}$ of the cultures did not surpass 8.7 , i.e. the minimum $\mathrm{pH}$ for precipitation, carbonate has been formed but did not precipitate (Loewenthal and Marais 1982; Ferris et al 2003; Dupraz et al 2009; Gebauer et al 2010). In addition, it has been stated that calcium carbonate can be formed at very low solubility levels in pure water before precipitation; its solubility in pure water is as low as $13 \mathrm{mg} \mathrm{L}^{-1}$ at $25^{\circ} \mathrm{C}$ (Aylward et al 2008); it increases relatively with decreasing temperature and increases in rainwater saturated with carbon dioxide, due to the 
formation of more soluble calcium bicarbonate. For the great majority of calcium carbonate precipitations, qualitative and descriptive assessments are dominant because most studies are carried out on calcium carbonate structures formed decades or hundreds of years ago while quantitative assessments are scarce. In this respect, MICP quantities of precipitated calcium after six treatments to Bacillus sp. were 0.15 and $0.60 \mathrm{~g}$ of Ca per $\mathrm{cm}^{2}$ of treated sand surface for bulk or surface MICP, respectively (Chu et al 2012). Also, a putative calcium carbonate mineral mass of $2.5 \mathrm{mg} / \mathrm{OD} 660$ has been reported in Bacillus sp. JH7 (Kim et al 2017). In this concert, Declet et al (2016) reported that synthesis of the particles involves some environmental variables including $\mathrm{pH}$, temperature, concentration of solutions, concentration and type of additives (organic or inorganic) and the substrate surface roughness, which play a decisive role in the formation of calcium carbonate particles.

While multiple microbial metabolic activities have been described in the literature to empower MICP by providing a potentially major source of ammonia (shifting the $\mathrm{pH}$ around the cell to the alkaline side) and $\mathrm{CO}_{2}$, which precipitates with calcium as carbonate precipitates (e.g. Anbu et al 2016), MICP of $D$. flosaquae mostly relied on or empowered by photosynthesis and respiration under conditions of this work. Urease activity, the most universal metabolic process supporting MICP, is not participating in this case, as the growth media was not supplemented with urea; despite the organism under test $D$. flosaquae exhibited potential urease specific activity in in vitro assays (four times that of the control at $4 \mathrm{mg} \mathrm{Ca}^{2+}$ citrate $\mathrm{L}^{-1}$ ). However, the high ability of $D$. flosaquae to shift the $\mathrm{pH}$ to alkalinity, without urea and urease being included in the culture medium, indicates sources of alkalinity other than the urease-dependent ammonia production, i.e. photosynthesis and respiration in the present case. In this context, aerobic bacteria release $\mathrm{CO}_{2}$ via cell respiration, which is paralleled by an increase in pH due to ammonia production ( $\mathrm{Ng}$ et al 2012). Hamilton et al (2009) stated that lakes in carbonate-rich watersheds commonly precipitate calcium carbonate as calcite; this is accelerated by photosynthetic uptake of carbon dioxide, elevating the $\mathrm{pH}$ to $9-10$ and reducing concentrations of calcium and alkalinity by up to $60 \%$. However, urea hydrolytic strains showed higher calcite precipitation ( 20-80\%) in comparison with other metabolic pathways (Achal et al 2009); despite the amount of $\mathrm{CaCO}_{3}$ precipitates depends more on $\mathrm{Ca}^{2+}$ concentrations (Okwadha and $\mathrm{Li} 2010$ ). 
The in vitro assay of UE (EC 3.5.1.5), per se, was also affected by calcium concentration and salt type i.e. it was inhibited by calcium deprivation while it exhibited maxima at 1.5, 2 and $4 \mathrm{mg} \mathrm{Ca}^{2+} \mathrm{L}^{-1}$ for chloride, acetate, and citrate, respectively. Calcium induces UE activity; Hammes et al (2003) found that UE activity increased by tenfold in the presence of $30 \mathrm{mM} \mathrm{Ca}^{2+}$ relative to its absence. UE activity is related to cell ( $\mathrm{Ng}$ et al 2012), urea and calcium concentrations (De Muynck et al 2010), and high $\mathrm{pH}$ (Jones et al 1982). In addition, UE is only active at high $\mathrm{pH}$ values specific for urea hydrolysis. It has been reported that the optimum $\mathrm{pH}$ for UE is 8.0, above which the enzyme activity decreases (Stocks-Fischer et al 1999; Gorospe et al 2013). In this work, the results indicate that UE activity of Dolichospermum flosaquae was enhanced due to an increase in specific activity of the enzyme rather than to higher cell numbers or biomass. Urease and carbonic anhydrase expression and activities are genetically and synergistically co-regulated for MICP (Dhami et al 2014; Castro-Alonso et al 2019).

Residual calcium was the least in the citrate-treated cultures, compared with other salts (chloride or acetate). At $4 \mathrm{mg} \mathrm{Ca}^{2+} \mathrm{L}^{-1}$ of citrate, in particular, the lowest residual $\mathrm{Ca}^{2+}$ level coincided with the highest alkalinity level, indicating its transformation to calcium carbonate. Consumed calcium per unit chlorophyll a was increased to its highest level also at $4 \mathrm{mg} \mathrm{Ca}^{2+} \mathrm{L}^{-1}$ of citrate treated cultures. In this respect, Kim et al (2017) reported that Bacillus sp. JH7 decreased the remaining ionized calcium to zero, which suggested that $\mathrm{Ca}^{2+}$ was either precipitated as $\mathrm{CaCO}_{3}$ or simply absorbed onto the exopolysaccaride (EPS) mucilaginous sheath of strain JH7. In conclusion, not all the disappearing calcium from the outer media is precipitated as MICP but it can be hidden onto the EPS sheaths of the cyanobacterium. In accordance with this, Silver et al (1975) reported that it is unlikely that $\mathrm{Ca}^{2+}$ is utilized by metabolic processes but accumulates outside the cells where it is readily available for $\mathrm{CaCO}_{3}$ precipitation. In this work, however, the unique and superior stimulating effect of $4 \mathrm{mg} \mathrm{Ca}^{2+} \mathrm{L}^{-1}$ calcium citrate compared with other salts (chloride or acetate) implies intracellular intervention of calcium ions as well as the accompanying anion in the intracellular metabolism. In this respect, citrate may serve at the same time as a carbon source and internal buffer.

Overall, calcium carbonate precipitation has been studied in natural (modern and ancient) geological structures as well as at controlled laboratory experiments. Natural 
deposits represent a collective mixture of interfered multiple factors, not at least because of space, time, and interconnected microbes (products and processes). In contrast, experimental modelling in MICP biogenesis uses pure microbial cultures, defines the role a specific microorganism plays at a specific environmental condition. Although calcium carbonate precipitation occurs chemically, a microorganism is essential for durable and stable calcium carbonate structures. In line with this notion, Stocks-Fischer et al (1999) reported that at pH 9.0, only 35 and $54 \%$ of the initial $\mathrm{Ca}^{2+}$ concentrations precipitated chemically in water and medium, respectively while $98 \%$ were precipitated microbially. Berry et al (2002) reported that though the oceans are supersaturated with $\mathrm{Ca}^{2+}$ and $\mathrm{CO}_{3}{ }^{2-}$, spontaneous precipitation of $\mathrm{CaCO}_{3}$ in the absence of calcifying (micro)- organisms is rare owing to various kinetic barriers. Thus, the process in nature is inefficient and the presence of a microorganism or part of it (cell walls, spores, chitin or mucilage) is indispensable for efficient calcification. It has also been reported that the largest share of global calcification takes place via biotic processes in the oceans (Olajire 2013). Microbially mediated calcification can be traced back for at least 2.6 billion years (Altermann et al 2006). The authors proposed that the interplay of cyanobacteria and heterotrophic bacteria has been the major contributor to the carbonate factory for roughly the last 3 billion years of Earth history. It is very hard to compare the MICP activity of a uni-cyanobacterial culture (Dolichospermum flosaquae), grown at laboratory conditions for a limited period of time, with a process occurring 1) in nature 2) by numerous consortia of microorganisms, 3) for a long-lasting time (billions of years), 4) under variable conditions over time, e.g. temperature, competition, synchronization and/or allelopathy. Under natural conditions, the precipitation of carbonates takes place very slowly over long geological times but in order to produce large amounts of carbonates shortly there is a need to focus on microorganisms that have the ability to create conditions for carbonate precipitation at much shorter time scales (Dhami et al 2013).

\section{Conclusions}

- Dolichospermum flosaquae, a major representative of temperate freshwater cyanobacteria, contributes to the microbially-induced calcium carbonate 


\section{Author contribution}

The first author (R. Abdel-Basset), designed the work, implemented the experiments, and wrote the drafts, the second author (E.A. Hassan), helped in the experiments and calculated the standard errors, the third author (H.P. Grossart) hosted the first two authors in his lab in IGB and revised the manuscript.

\section{Competing interests}

There are no competing interests among authors.

404

405

\section{Acknowledgment}

Prof. Dr. R. Abdel-Basset sincerely thanks the Alexander von Humboldt Stiftung for the generous financial coverage of his research stay in the lab of Prof. Dr. H. P. Grossart, Leibiniz Institute for Freshwater Ecology and Inland Fisheries (IGB), and thanks to the MIBI group for their help.

\section{References}


Achal, V. and Pan, X.: Influence of calcium sources on microbially induced calcium carbonate precipitation by Bacillus sp. CR2. Appl Biochem. Biotechnol.,173:307317. doi: 10.1007/s12010-014-0842-1, 2014.

Achal, V., Mukherjee, A., Basu, P.C. and Reddy, M.S.: Strain improvement of Sporosarcina pasteurii for enhanced urease and calcite production. J. Ind. Microbiol. Biotechnol., 36:981-988. doi: 10.1007/s10295-009-0578-z, 2009.

Alderkamp, A.-C., Mills, M. M., van Dijken, G. L., Laan, P., Thuroczy, C.-E., Gerringa, L. J. A., de Baar, H. J. W., Payne, C. D., Visser, R. J. W., Buma, A. G. J., and Arrigo, K. R.: Iron from melting glaciers fuels phytoplankton blooms in the Amundsen Sea (Southern Ocean): Phytoplankton characteristics and productivity, Deep-Sea Res. Pt. II, 71-76, 32-48, https://doi.org/10.1016/j.dsr2.2012.03.005, 2012.

Allen, C. S., Peck, V. L., Graham, A. G. C., Blagbrough, H., Robinson, M. W., and McClymont, E.: RRS James Clark Ross Marine Science Cruises JR257 and JR254e, March-April 2012, British Antarctic Survey, Cambridge, UK, https://www.bodc.ac.uk/resources/inventories/cruise_inventory/reports/jr257_25 4e.pdf, 2012.

Altermann, W., Kazmierczak J., Oren A., Wright D.T. (2006): Cyanobacterial calcification and its rock-building potential during 3.5 billion years of Earth history, Geobiology 4, 147-166. Doi: - 10.1111/j.1472-4669.2006.00076.x.

Anbu P., Kang C.H., Shin Y.J. and So J.S. (2016): Formations of calcium carbonate minerals by bacteria and its multiple applications. Springer Plus 5:250. doi: 10.1186/s40064-016-1869-2.

Aylward, Gordon; Findlay, Tristan (2008). SI Chemical Data Book (4th ed.). John Wiley \& Sons Australia. ISBN 978-0-470-81638-7.

Berry L., Taylor A.R., Lucken U., Ryan K.P. and Brownlee C. (2002): Calcification and inorganic carbon acquisition in coccolithophores. Funct. Plant Biol. 9:289-299.

Bradford M. M. (1976): A rapid and sensitive method for the quantitation of microgram quantities of protein utilizing the principle of protein-dye binding. Anal Biochem. $72,248-254$.

Castro-Alonso M.J., Montañez-Hernandez L.E., Sanchez-Muñoz M.A., Franco M.R.M., Narayanasamy R. and Balagurusamy N. (2019): Microbially induced calcium carbonate precipitation (MICP) and its potential in bioconcrete: 
Microbiological and Molecular Concepts. Front. Mater., 6(126): https://doi.org/10.3389/fmats.2019.00126.

Choi S.-G., Park S.-G., Wu S. and Chu J. (2017): Methods for calcium carbonate content measurement of biocemented soils. J. Mater. Civ. Eng. 29(11): 06017015(1-4).

Chu J., Stabnikov V. and Ivanov V. (2012): Microbially induced calcium carbonate precipitation on surface or in the bulk of soil. Geomicrobiology Journal, 29:544549.

De Muynck W., De Belie N. and Verstraete W. (2010): Microbial carbonate precipitation in construction materials: a review. Ecol Eng. 36:118-136. doi: 10.1016/j.ecoleng.2009.02.006.

Declet, A., Reyes, E., and Suárez, O. M. (2016). Calcium carbonate precipitation: a review of the carbonate crystallization process and applications in bioinspired composites. Rev. Adv. Mater. Sci. 44, 87-107.

Dhami N. K., Reddy M. S. and Mukherjee A. (2014): Application of calcifying bacteria for remediation of stones and cultural heritages. Front. Microbiol. Vol. 5:304. doi: 10.3389/fmicb.2014.00304.

Dhami N.K., Reddy M.S. and Mukherjee A. (2013): Biomineralization of calcium carbonate polymorphs by the bacterial strains isolated from calcareous sites. $\mathrm{J}$ Microbiol Biotechnol. 23:707-714. doi: 10.4014/jmb.1212.11087.

Dupraz S., Menez B., Gouze P., Leprovost R., Benezeth P., Pokrovsky O.S. and Guyot F. (2009): Experimental approach of $\mathrm{CO}_{2}$ biomineralization in deep saline aquifers. Chem Geol. 265:54-62. doi: 10.1016/j.chemgeo.2008.12.012.

Ferris F.G., Phoenix V., Fujita Y. and Smith R.W. (2003): Kinetics of calcite precipitation induced by ureolytic bacteria at 10 to $20^{\circ} \mathrm{C}$ in artificial groundwater. Geochim. Cosmochim. Acta. 67:1701-1710.

Gebauer D., Gunawidjaja P.N., Peter Ko J.Y., Bacsik Z., Aziz B., Liu L., Hu Y., Bergstrom L., Tai C.W., Sham T.K., Eden M. and Hedin N. (2010): Proto-calcite and proto-vaterite in amorphous calcium carbonates. Angew Chem Int Ed. 49:8889-8891. doi: 10.1002/anie.201003220. 
Gorospe C.M., Han S.H., Kim S.G., Park J.Y., Kang C.H., Jeong J.H. and So J.S. (2013): Effects of different calcium salts on calcium carbonate crystal formation by Sporosarcina pasteurii KCTC 3558. Biotechnol. Bioproc. Eng. 18:903-908. doi: 10.1007/s12257-013-0030-0.

Hamilton S.K., Bruesewitz D.A., Horst G.P., Weed D.B. and Sarnelle O. (2009): Biogenic calcite-phosphorus precipitation as a negative feedback to lake eutrophication. Can. J. Fish. Aquat. Sci., 66: 343-350.

Hammes F, Boon N, de Villiers J, Verstraete W and Siciliano SD. (2003): Strainspecific ureolytic microbial calcium carbonate precipitation. Appl Environ Microbiol. 69:4901-4909. doi: 10.1128/AEM.69.8.4901-4909.2003.

Jeziorski A. and Smol J.P. (2017): The ecological impacts of lake water calcium decline on soft water boreal ecosystems. Environ. Rev., 25: 245-253.

Jeziorski A., Paterson A.M., Watson I., Cumming B.F. and Smol J.P. (2014): The influence of calcium decline and climate change on the cladocerans within low calcium, circumneutral lakes of the experimental lakes area. Hydrobiologia 722 : 129-142.

Kim H.J., Shin B., Lee Y.S. and Park W. (2017): Modulation of calcium carbonate precipitation by exopolysaccharide in Bacillus sp. JH7. Appl Microbiol Biotechnol 101, 6551-6561. https://doi.org/10.1007/s00253-017-8372-8.

Korosi J.B., Burke S.M., Thienpont J. R. and Smol J. P. (2012): Anomalous rise in algal production linked to lake water calcium decline through food web interactions Proc Biol Sci. Mar 22; 279(1731): 1210-1217. doi: 10.1098/rspb.2011.1411.

Loewenthal R. E., and Marais G.V.R. (1982): Carbonate chemistry of aquatic systems, In H.-J. Walther (ed.). Theorie and Application, V.1, 433 pp. USA, Michigan, Collingwood, Ann Arbor Scienc Publishers, Third Printing 1982. ISBN 0 - 250 40141 - X

Mobley H.L.T., Cortesia M.J., Rosenthal L.E. and Jones B.D. (1988): Characterization of urease from Campylobacter pylori. Journal of Clinical Microbiology, 26(5): 831836.

Ng S.W., Lee M.L. and Hii S.L. (2012): An overview of the factors affecting microbialinduced calcite precipitation and its potential application in soil improvement. World Acad Sci Eng Technol. 62:723-729. 
Okwadha GDO and Li J. (2010): Optimum conditions for microbial carbonate precipitation. Chemosphere 81:1143-1148. doi: 10.1016/j.chemosphere.2010.09.066.

Payandi-Rolland D., Roche A., Vennin E., Visscher P.T., Suchet P.A., Camille Thomas C. and Bundeleva I.A. (2019): Carbonate precipitation in mixed cyanobacterial biofilms forming freshwater microbial tufa. Minerals 2019, 9, 409: 1-20; doi:10.3390/min9070409.

Phillips A.J., Gerlach R, Lauchnor E, Mitchell AC, Cunningham AB, Spangler L. (2013): Engineered applications of ureolytic biomineralization: a review. Biofouling.; 29(6):715-33. doi: 10.1080/08927014.2013.79655.

Salek S.S., Bozkurt O.D., van Turnhout A.G., Kleerebezem R. and van Loosdrecht M.C.M. (2016): Kinetics of $\mathrm{CaCO}_{3}$ precipitation in an anaerobic digestion process integrated with silicate minerals. Ecological Engineering 86: 105-112.

Seifan M., Berenjian A. and Aydin B. (2019): Microbially induced calcium carbonate precipitation: a widespread phenomenon in the biological world. Applied Microbiology and Biotechnology. 103. 10.1007/s00253-019-09861-5.

Silver S, Toth K. and Scribner H. (1975): Facilitated transport of calcium by cells and subcellular membranes of Bacillus subtilis and Escherichia coli. J Bacteriol. 122:880-885.

Rippka R. and Herdman M. ((1993): Catalogue and Taxonomic Handbook, vol. 1, Insitut Pasteur, Paris.

Stocks-Fischer S., Galinat J.K. and Bang S.S. (1999): Microbiological precipitation of $\mathrm{CaCO}_{3}$. Soil Biol. Biochem. 31:1563-1571. doi: 10.1016/S0038-0717(99)000826.

Weyhenmeyer G. A., Hartmann J., Hessen D.o., Jiří Kopáček, Hejzlar J., Jacquet S., Hamilton S.K., Verburg P., Leach T.H., Schmid M., Flaim G., Nõges T., Nõges P., Wentzky V.C., Rogora M., Rusak J.A., Kosten S., Paterson A.M., Teubner K., Higgins S.N., Lawrence G., Kangur K., Kokorite I., Cerasino L., Funk C., Harvey R., Moatar F., de Wit H.A. and Zechmeister T. (2019): Widespread diminishing anthropogenic effects on calcium in freshwater. Scientific Reports, 9:10450. https://doi.org/10.1038/s41598-019-46838-ws 
Xu H., Peng X., Bai S., Ta K., Yang S., Liu S., Jang H.B. and Guo Z. (2019). Precipitation of calcium carbonate mineral induced by viral lysis of cyanobacteria: evidence from laboratory experiments. Biogeosciences 16:949-960. doi: 10.5194/bg-16-949-2019.

Yanamadala V. (2005): Calcium carbonate phosphate binding ion exchange filtration and accelerated denitrification improve public health standards and combat eutrophication in aquatic ecosystems. Water Environ Res. 77(7): 3003-3012.

\section{Figure legends}

Figure (1): Growth as cell number $\left(\times 10^{3}\right.$ cells $\left.\mathrm{mL}^{-1}\right)$, chlorophyll $\left(\times 10^{3} \mu \mathrm{g} \mathrm{mL}^{-1}\right)$ and protein contents $\left(\mu \mathrm{g} \mathrm{mL}^{-1}\right)$ of the cyanobacterium Dolichospermum flosaquae as influenced by various calcium treatments: Control (B), 0, 1, 1.5, 2 and $4 \mathrm{mM}$ of calcium chloride $(\mathrm{Cl})$, calcium acetate $(\mathrm{A})$ and calcium citrate $(\mathrm{Ct})$. Control cultures were grown in BG11 medium containing $13 \mathrm{mg} \mathrm{Ca}^{2+} \mathrm{L}^{-1}$ (chloride), 0 is calcium deprived, i.e. not supplemented with any external calcium.

Figure (2): Changes in the $\mathrm{pH}$ of the cyanobacterium Dolichospermum flosaquae cultures as influenced by calcium treatments (as in figure 1).

Figure (3): Photosynthesis and respiration rates of the cyanobacterium Dolichospermum flosaquae as influenced by calcium treatments (as in figure 1).

Figure (4): Total alkalinity (carbonate and ammonia as mmol. $\mu \mathrm{g} \mathrm{Chl}^{-1}$ ) of the cyanobacterium Dolichospermum flosaquae as influenced by calcium treatments (as in figure 1).

Figure (5): Residual ( $\left.\mathrm{mg} \mathrm{L}^{-1}\right)$, total ( $\left.\mathrm{mg} \mathrm{L}^{-1}\right)$ and consumed calcium ( $\mathrm{mg} \mathrm{L}^{-1}$ or $\mathrm{mg} . \mu \mathrm{g}$ $\mathrm{Chl}^{-1}$ ) of the cyanobacterium Dolichospermum flosaquae as influenced by calcium treatments (as in figure 1).

Figure (6): Urease activity, T (total) and SA (Specific Activity) of the cyanobacterium Dolichospermum flosaquae as influenced by calcium treatments (as in figure 1). 


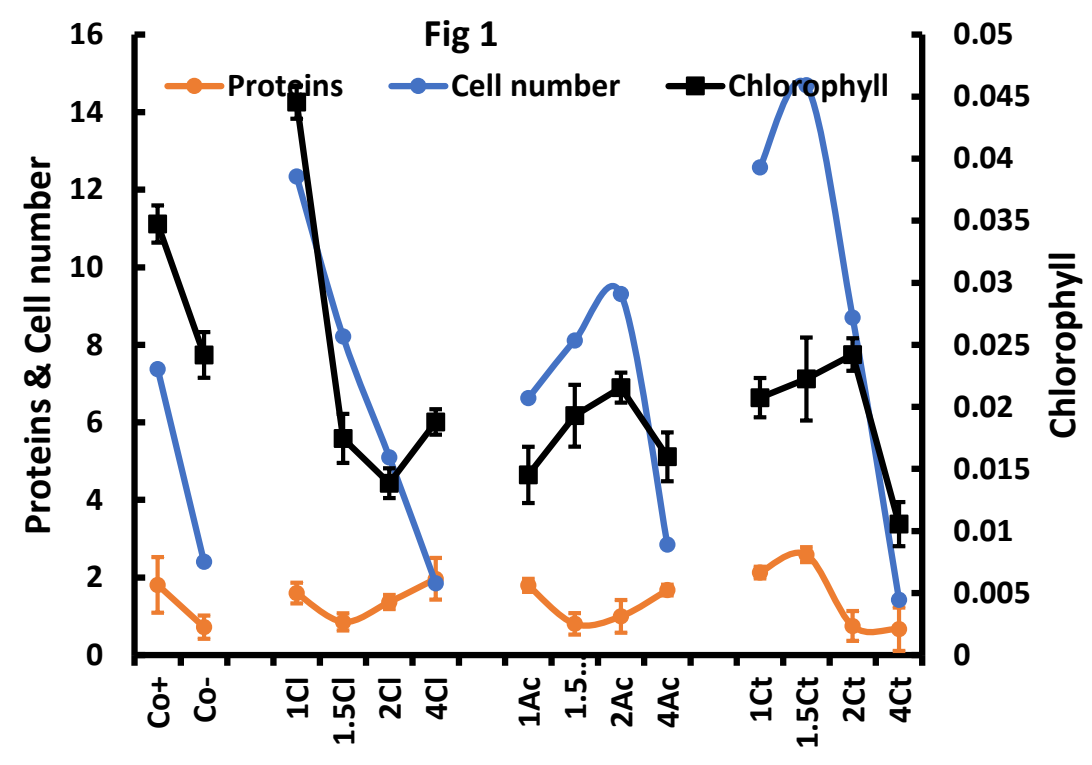



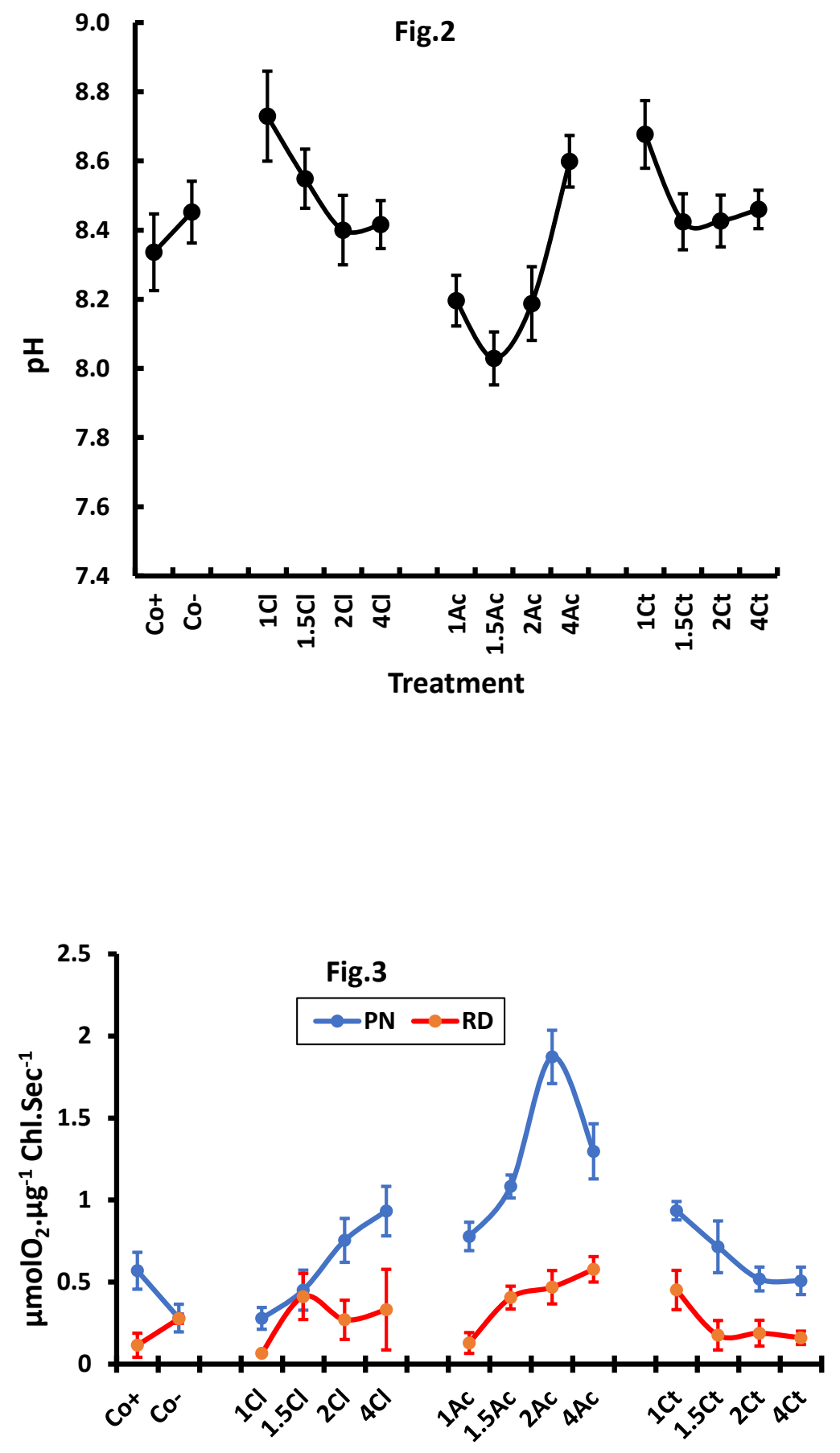

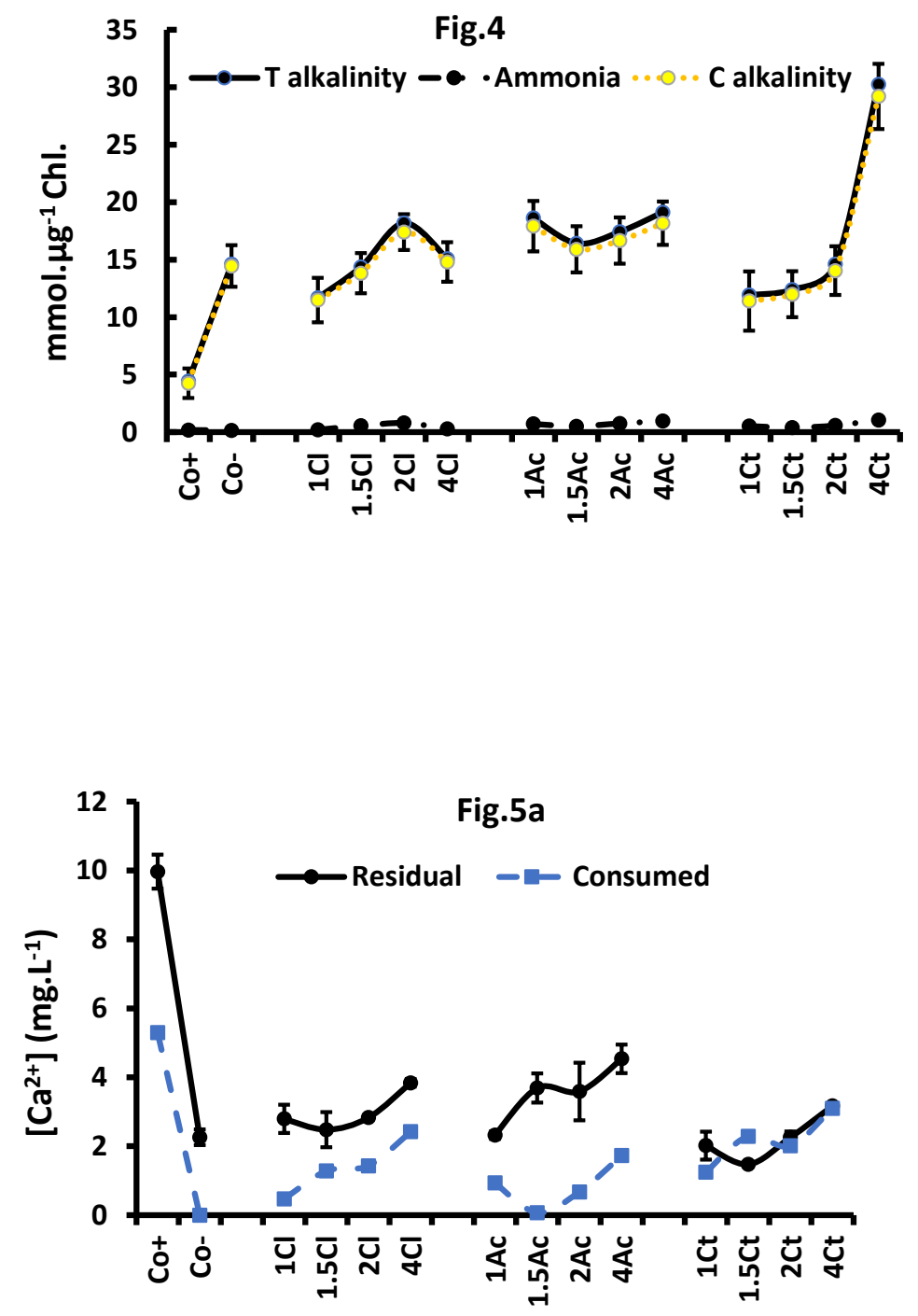

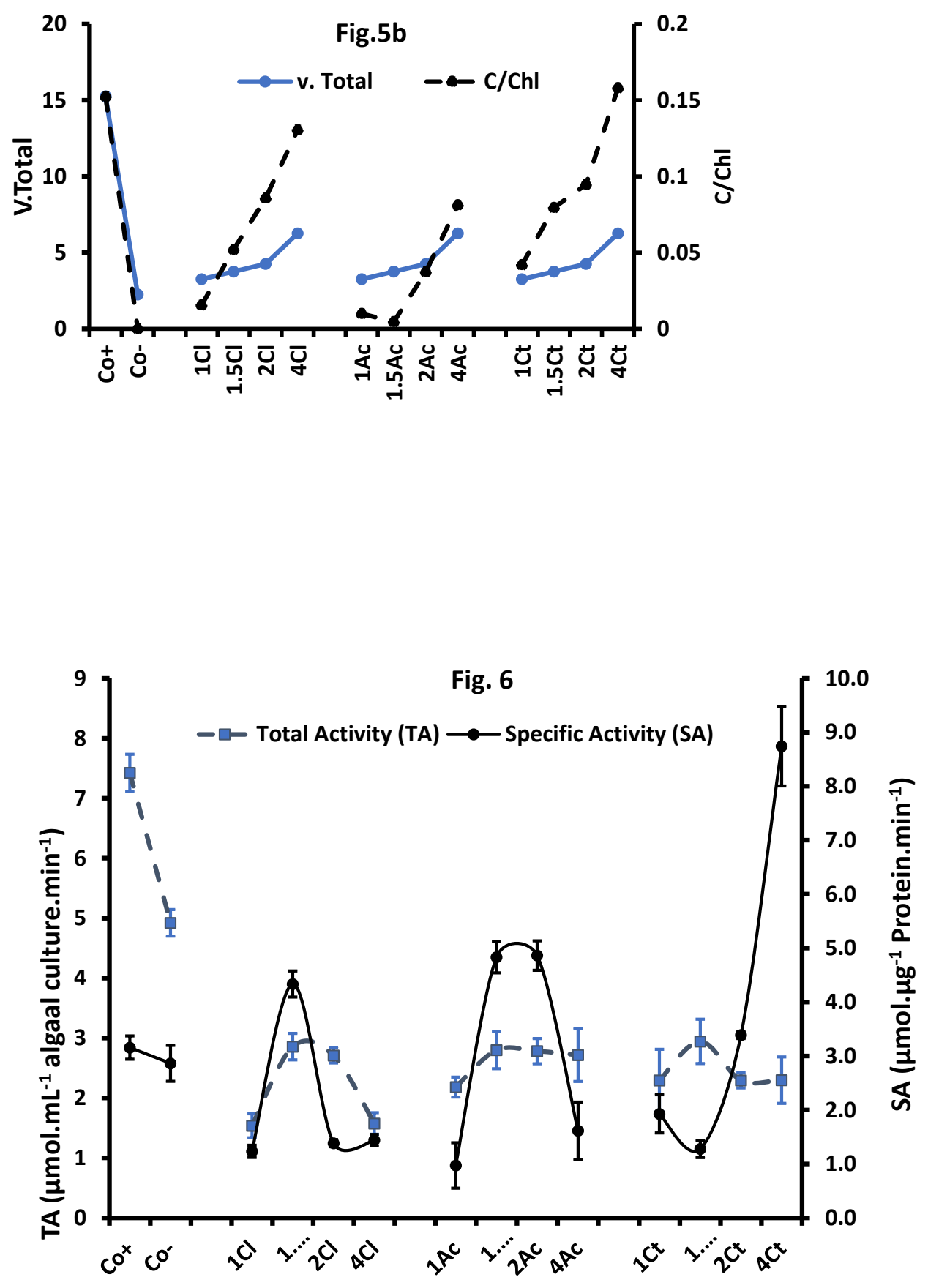